\title{
Do Utility Stocks Provide Exposure To Bond Markets?
}

Carol Boyer, Long Island University, USA

Stephen J. Ciccone, University of New Hampshire, USA

\begin{abstract}
This study examines the relationship between utility stock returns and various bond or interest rate index returns. In contrast to the $S \& P 500$ index, utility stocks show a positive relationship to bond returns. Utility stocks also are more correlated with corporate bond returns than the stock indexes. Overall, utility stocks are considered an excellent diversification tool. The upside of the stock market can be captured, but with less downside risk.
\end{abstract}

Keywords: Utility stocks, Dividends, Bond Market, Garch model, Time series

\section{INTRODUCTION}

nvestors seeking low risk and income could consider investing in investment grade bonds. Investors
seeking low risk, income, with the added potential for capital appreciation could also consider investing
in utility stocks. However, utility stocks may be overlooked due to a perceived lack of capital appreciation and investors seeking stability head directly to bonds and neglect to consider utility stocks as an investment, when utility stocks may actually have some of the benefits of both bonds and stocks.

In times of economic trouble, investors often flock to safe havens such as Treasury securities. While Treasury securities offer low risk and peace of mind, their expected returns may be too low for the typical stock market investor. Utility stocks may offer an attractive alternative. Due to their high dividend yields and recessionproof services, utility stocks are often praised by the financial press for their ability to perform well in down markets (e.g., McMillan, 2000; Hulbert, 2006). Indeed, as noted by Hulbert (2006), utility stocks have recently soared to record levels, while the tech-heavy Nasdaq Composite is at less than half its all-time high.

Unfortunately, utility stocks are seen as not "sexy" enough, and as a result, they may be avoided by investors typically concerned with the latest high-tech products or trendy foreign markets. However, utilities may appear much more interesting if they are marketed as a way to gain exposure to the bond market and receive the benefits of the bond market such as lower risk through an equity security. Not only do utility stocks have the potential for capital appreciation, but they also provide an additional advantage in that they may raise their dividend (de Aenlle, 1992).

The goal of this study is to examine utility stock returns to determine the level of exposure they provide to the bond market. Despite being oft-praised by the financial press, surprisingly little empirical research has separately examined utility stock returns. We hope to fill some of that void.

While utility stocks, like bonds, are thought to be good performers in down markets, they may compete for the same investor dollars (Choe, 2007). If true, utilities may not provide adequate exposure to bonds.

Dividend paying utility stocks may also provide a better inflation hedge relative to bonds. During inflationary time periods, the prices and dividends of utility stocks, may increase more readily, compared to bonds, as regulated utilities can receive set price increases through regulations. Utility stocks are typically in regulated industries and have the ability to raise rates when their costs rise. Thus a utility stock will be in the position to raise dividends and potentially have capital appreciation, whereas the interest and principal on a bond will not rise with 
inflation. Furthermore, in a rising interest rate environment, which is typically an inflationary time period, the price of bonds will fall, whereas utility stock price may increase due to rising utility rates. Thus, utility stocks will be able to raise rates to keep pace with inflation and thus, potentially raise the dividend to keep their stockholder clientele happy.

\section{METHODOLOGY}

Bond data is obtained from the St. Louis Federal Reserve (FRED) database. The database includes monthly yields for the Federal Funds rate, several types of Treasury bonds, and an S\&P Aaa corporate bond index. Bond returns are approximated by first converting the yield into a discounted price (price $=100-$ yield). These discounted prices are then used to compute the capital gain or loss for the month (in percent). The interest portion is then computed by taking the beginning-of-period annual bond yield and dividing by 12 months. The interest portion is then added to the capital gain or loss to obtain the bond return for the month.

This study utilizes the Federal Funds rate (Fed Funds) to capture short-term interest rates, the 10-Year Treasury Bond (10-Year Treasury) to capture long-term Treasury bond rates, and the Aaa Corporate Bond Index (Aaa) to capture corporate bond rates. The 10-Year Treasury Bond has an uninterrupted time series of return data from April 1953 through December 2007. The Federal Funds return data begins in July 1954 and continues uninterrupted through December 2007. Although the corporate bond data begins in 1919, its data is truncated to correspond to the 10-Year Treasury.

Stock returns are obtained from the Center for Research in Security Prices (CRSP) database. An equally weighted utility stock index, EW Utilities, is created by obtaining all stocks with SIC codes between 4900 and 4960. The average monthly returns including distributions of all the utility firms are then computed. An average of 151 stocks is contained in EW Utilities per month

The CRSP database includes two total market indexes, one equally weighted, the other value weighted. The CRSP database also provides returns on the S\&P 500 Index. These indexes are used for comparison purposes and are called EW CRSP, VW CRSP, and S\&P 500. EW CRSP and VW CRSP returns include distributions. The S\&P 500 returns are computed based on the index level.

The final sample period includes the 657 months from April 1953 through December 2007. The time series regressions begin in July 1954 because they include Fed Funds, thus extending over 642 months.

\section{RESULTS}

Exhibit 1 presents summary monthly return statistics for $E W$ Utilities and several bond and stock indexes. The summary statistics are presented for all months and also for up and down markets as defined using the S\&P 500 . The mean returns corroborate the claims of the financial press. The mean return of $E W$ Utilities is almost as high as $E W C R S P$ and higher than $S \& P 500$ and VW CRSP despite lower monthly return volatility. The reason for this is simple: utilities perform better in down markets, losing only $1 \%$ per month on average while the S\&P loses over $3 \%$.

Exhibit 2 presents correlation coefficients between the various bond and stock indexes. EW Utilities is significantly positively correlated with all bond index returns. In contrast, all three broad stock indexes are either insignificantly or negatively correlated with Fed Funds and 10-Year Treasury. EW CRSP and VW CRSP are also insignificantly related to Aaa. While $S \& P 500$ is positively correlated with $A a a$, its magnitude of 0.07 is $1 / 3$ that of the correlation between EW Utilities and Aaa (0.21). The results indicate that an investor could invest in a utility equity and derive some of the benefits of investing in bonds, namely safety and lower risk, while receiving some of the benefits of investing in equities, such as capital appreciation. In some sense, it could be considered a hybrid security. 
Exhibit 1: Summary Statistics of Monthly Returns

\begin{tabular}{|c|c|c|c|c|c|c|c|}
\hline & Mean & Std Dev & Minimum & $25^{\text {th }} \%$ & Median & $75^{\text {th }} \%$ & Maximum \\
\hline & \multicolumn{7}{|c|}{ All Months (Max N=657) } \\
\hline EW Utilities & 0.0106 & 0.0345 & $-0.127 \overline{5}$ & -0.0098 & 0.0123 & 0.0296 & 0.2412 \\
\hline Fed Funds & 0.0047 & 0.0071 & -0.0242 & 0.0018 & 0.0038 & 0.0066 & 0.0951 \\
\hline 10-Year Treasury & 0.0054 & 0.0039 & -0.0090 & 0.0030 & 0.0046 & 0.0070 & 0.0334 \\
\hline Aaa & 0.0060 & 0.0034 & -0.0053 & 0.0036 & 0.0055 & 0.0074 & 0.0268 \\
\hline S\&P 500 & 0.0071 & 0.0411 & -0.2176 & -0.0175 & 0.0091 & 0.0347 & 0.1630 \\
\hline VW CRSP & 0.0098 & 0.0421 & -0.2253 & -0.0161 & 0.0132 & 0.0377 & 0.1656 \\
\hline \multirow[t]{2}{*}{ EW CRSP } & 0.0122 & 0.0531 & -0.2722 & -0.0177 & 0.0145 & 0.0418 & 0.2993 \\
\hline & \multicolumn{7}{|c|}{$\underline{S} \& \mathrm{P} 500=$ Negative $(\mathrm{Max} N=266)$} \\
\hline EW Utilities & -0.0116 & 0.0295 & -0.1275 & -0.0285 & -0.0093 & 0.0080 & 0.0551 \\
\hline Fed Funds & 0.0050 & 0.0074 & -0.0239 & 0.0017 & 0.0036 & 0.0069 & 0.0548 \\
\hline 10-Year Treasury & 0.0057 & 0.0038 & -0.0029 & 0.0032 & 0.0050 & 0.0072 & 0.0253 \\
\hline Aaa & 0.0060 & 0.0034 & 0.0002 & 0.0036 & 0.0056 & 0.0073 & 0.0227 \\
\hline S\&P 500 & -0.0310 & 0.0281 & -0.2176 & -0.0434 & -0.0226 & -0.0110 & 0.0000 \\
\hline VW CRSP & -0.0288 & 0.0304 & -0.2253 & -0.0407 & -0.0226 & -0.0094 & 0.0317 \\
\hline \multirow[t]{2}{*}{ EW CRSP } & -0.0270 & 0.0466 & -0.2722 & -0.0502 & -0.0226 & -0.0004 & 0.1500 \\
\hline & \multicolumn{7}{|c|}{$\underline{\text { S\&P } 500=\text { Positive }(\mathrm{Max} N=391)}$} \\
\hline EW Utilities & 0.0258 & 0.0290 & -0.0525 & 0.0081 & 0.0220 & 0.0402 & 0.2412 \\
\hline Fed Funds & 0.0045 & 0.0069 & -0.0242 & 0.0018 & 0.0039 & 0.0064 & 0.0951 \\
\hline 10-Year Treasury & 0.0052 & 0.0039 & -0.0090 & 0.0029 & 0.0043 & 0.0069 & 0.0334 \\
\hline Aaа & 0.0060 & 0.0034 & -0.0053 & 0.0036 & 0.0055 & 0.0076 & 0.0268 \\
\hline S\&P 500 & 0.0329 & 0.0254 & 0.0001 & 0.0132 & 0.0279 & 0.0453 & 0.1630 \\
\hline VW CRSP & 0.0361 & 0.0254 & -0.0083 & 0.0175 & 0.0315 & 0.0498 & 0.1656 \\
\hline EW CRSP & 0.0389 & 0.0389 & -0.0418 & 0.0154 & 0.0342 & 0.0593 & 0.2993 \\
\hline
\end{tabular}

This table reports summary statistics of monthly returns. The statistics are computed for all sample months and after separating months into two groups based on the return of the S\&P 500 Index.

Exhibit 2: Correlations between Various Stock and Bonds Indexes

\begin{tabular}{|c|c|c|c|c|c|c|c|}
\hline & $\begin{array}{l}\text { EW } \\
\text { Utilities }\end{array}$ & Fed Funds & $\begin{array}{l}\text { 10-Year } \\
\text { Treasury }\end{array}$ & Aaa & S\&P 500 & VW CRSP & EW CRSP \\
\hline EW Utilities & 1.00 & & & & & & \\
\hline Fed Funds & $0.15 * * *$ & 1.00 & & & & & \\
\hline 10-Year Treasury & $0.12 * * *$ & $0.46^{* * *}$ & 1.00 & & & & \\
\hline Aaa & $0.21 * * *$ & $0.46 * * *$ & $0.92 * * *$ & 1.00 & & & \\
\hline S\&P 500 & $0.69 * * *$ & -0.03 & -0.04 & $0.07 *$ & 1.00 & & \\
\hline VW CRSP & $0.70 * * *$ & -0.02 & -0.04 & 0.06 & $0.98 * * *$ & 1.00 & \\
\hline EW CRSP & $0.61 * * *$ & -0.03 & $-0.10 * *$ & -0.01 & $0.78 * * *$ & $0.85 * * *$ & 1.00 \\
\hline
\end{tabular}

This table reports Pearson correlation coefficients. The ***,**, and * indicate the coefficient is significantly different from zero with $99 \%, 95 \%$, or $90 \%$, confidence, respectively.

Exhibit 3 presents the results of time series regression models. A GARCH $(1,1)$ model with five lags is specified. The dependent variable is either the EW Utilities or EW CRSP. The independent variables chosen are Fed Funds and Aaa. The model is specified for up months and down months using the S\&P 500 Index return to define up or down. 
Exhibit 3: Time Series Regression Models

\begin{tabular}{|c|c|c|c|c|c|c|}
\hline \multirow[b]{3}{*}{ Intercept } & \multicolumn{2}{|c|}{ All Months } & \multicolumn{2}{|c|}{ S\&P $500=$ Negative } & \multicolumn{2}{|c|}{ S\&P 500 = Positive } \\
\hline & EW Utilities & EW CRSP & EW Utilities & EW CRSP & EW Utilities & EW CRSP \\
\hline & $\begin{array}{l}-0.0059 * * * \\
(-3.01)\end{array}$ & $\begin{array}{l}0.0080 * * * \\
(3.93)\end{array}$ & $\begin{array}{l}-0.0028 \\
(-0.97)\end{array}$ & $\begin{array}{l}0.0137 * * \\
(2.36)\end{array}$ & $\begin{array}{l}-0.0084 * * * \\
(-2.58)\end{array}$ & $\begin{array}{l}0.0139 * * * \\
(3.61)\end{array}$ \\
\hline VW CRSP & $\begin{array}{l}0.5977 * * * \\
(31.28)\end{array}$ & $\begin{array}{l}1.0370 * * * \\
(58.37)\end{array}$ & $\begin{array}{l}0.6469 * * * \\
(15.38)\end{array}$ & $\begin{array}{l}1.2643 * * * \\
(21.18)\end{array}$ & $\begin{array}{l}0.6533 * * * \\
(19.20)\end{array}$ & $\begin{array}{l}0.9511 * * * \\
(23.81)\end{array}$ \\
\hline Fed Funds & $\begin{array}{l}0.6503 * * * \\
(3.81)\end{array}$ & $\begin{array}{l}0.1875 \\
(1.28)\end{array}$ & $\begin{array}{l}0.5198 * * \\
(2.56)\end{array}$ & $\begin{array}{l}0.0598 \\
(0.26)\end{array}$ & $\begin{array}{l}0.5860 * * * \\
(2.81)\end{array}$ & $\begin{array}{l}0.4793 * * \\
(2.14)\end{array}$ \\
\hline Aaa & $\begin{array}{l}1.2612 * * * \\
(3.68)\end{array}$ & $\begin{array}{l}-1.3425 * * * \\
(-4.90)\end{array}$ & $\begin{array}{l}1.0245^{* *} \\
(2.27)\end{array}$ & $\begin{array}{l}-0.7237 \\
(-0.88)\end{array}$ & $\begin{array}{l}1.3697 * * * \\
(2.69)\end{array}$ & $\begin{array}{l}-2.0982 * * * \\
(-4.14)\end{array}$ \\
\hline $\begin{array}{l}\mathrm{R}^{2} \\
\mathrm{~N}\end{array}$ & $\begin{array}{l}0.51 \\
642\end{array}$ & $\begin{array}{l}0.73 \\
642\end{array}$ & $\begin{array}{l}0.31 \\
262\end{array}$ & $\begin{array}{l}0.69 \\
262\end{array}$ & $\begin{array}{l}0.35 \\
380\end{array}$ & $\begin{array}{l}0.48 \\
380\end{array}$ \\
\hline
\end{tabular}

This tables reports the coefficients and t-statistics (in parentheses) of GARCH $(1,1)$ time series regression models with five lags. Either the equal weighted utilities index (EW Utilities) or the equal weighted CRSP index (EW CRSP) is the dependent variable. The value weighted CRSP Index (VW CRSP), the Federal Funds rate (Fed Funds), and the Aaa corporate bond rate (Aaa) are the independent variables. The GARCH-related and lagged coefficients and t-statistics are omitted from the presentation. The models are specified for all sample months and after separating months into two groups based on the return of the S\&P 500 Index. The $* * *, * *$, and * indicate the coefficient is significantly different from zero with $99 \%, 95 \%$, or $90 \%$, confidence, respectively.

The results indicate that the EW Utilities is positively related to both long-term and short-term interest rate fluctuations. This relationship holds in both up and down markets. In contrast, EW CRSP is unrelated to Fed Funds and is unrelated or negatively related to $A a a$. The fact that utility equities are positively related to interest rate changes indicates that they provide the equity investor with exposure to the bond market. Furthermore, given the positive relationship to interest rates, it is clear that utility equities do provide some hedge towards inflation, as well as the potential for capital appreciation and the ability to withstand market downturns.

\section{CONCLUSIONS}

Given their strong return performance for their level of risk, utility stocks are often considered good investments. The results of this study demonstrate that utility stocks provide exposure to the bonds markets. Such exposure is not provided by the broader market stock indexes used for comparison. While the relationship between utility stock returns and bond returns may produce lower returns versus the broad market indexes during up market months, this is counteracted by the higher utility returns in the many down market months. Overall, utility stocks provide investors with an excellent opportunity to gain exposure to the bond market through equity security and provide a hedge for inflation due to their regulated nature and ability to increase prices and thus dividends.

\section{AUTHOR INFORMATION}

Carol Boyer is an Assistant Professor of Finance at Long Island University - CW Post campus in Brookville, NY. She received her Ph.D. from Florida State University. Some of her publications include The Cambridge Journal of Economics, Advances in Investment Analysis and Portfolio Management, and Managerial Finance. She has presented research papers at the European FMA, EFA, Decision Sciences Institute, FMA, and the ABN AMRO International IPO Conference.

Stephen J. Ciccone is currently the Chair of the Accounting and Finance Department and an Associate Professor of Finance at the University of New Hampshire's Whittemore School of Business. He received a Ph.D. in Business Administration (Finance) from Florida State University in 2000. He also holds a Bachelor's and a Master's degree 
in accounting from the University of Florida. He worked as an auditor for Arthur Andersen from 1994 to 1996 and has been a CPA since 1995. His research has appeared in multiple finance and accounting journals. In 2006, he received the Whittemore School's Outstanding Researcher award.

\section{REFERENCES}

1. Choe, Stan. 2007. "Dowdy No More, Utilities are Top Stocks.” AP Business Wire, May 24, 2007.

2. deAnnelle. Xxx.

3. Hulbert, Mark. 2006. "The Revenge of Utilities. Commentary: Stocks May be Boring, but Average Utility Just Hit New High.” Dow Jones Market Watch, December 1, 2006.

4. McMillan, Alex Frew. 2000. "Unsexy Stocks Refind Zip." CNN Money, August 23, 2000. 
NOTES 